\title{
Using Participatory Action Research to Develop a Course Module on Education for Sustainable Development in Pre-Service Chemistry Teacher Education
}

MAREIKe Burmeister ${ }^{1}$ AND INgo EILKs ${ }^{\star 2}$

$\approx$ This paper describes the development of a course module on sustainability issues and Education for Sustainable Development in German pre-service chemistry teacher education. The module was inspired by empirical research findings about the knowledge base of student teachers. It was created and cyclically refined using Participatory Action Research. Experience gained during its three-year application will be reflected upon here, including feedback collected from student evaluation sheets. In the end, the participants responded extremely positively to the course. The student teachers stated that the module was interesting, relevant and valuable for their later profession as high school chemistry teachers. They also emphasised that they now felt more competent in the area of sustainability and ESD.

Keywords: Education for Sustainable Development, Chemistry Education, Participatory Action Research, Teacher Education

1 University of Bremen, Institute for Science Education, Leobener Str. NW 2, 28334 Bremen, Germany

$2{ }^{\star}$ Corresponding author: University of Bremen, Institute for Science Education, Leobener Str. NW 2, 28334 Bremen, Germany eilks@uni-bremen.de 


\section{Uporaba akcijskega raziskovanja z udeležbo pri razvoju učnega modula za izobraževanje za trajnostni razvoj pri bodočih učiteljih kemije}

Mareike Burmeister in INGo EILKs*

$\propto$ V prispevku je predstavljen razvoj učnega modula o trajnostnih temah in izobraževanju za trajnostni razvoj pri bodočih učiteljih kemije $\mathrm{v}$ Nemčiji. Modul je rezultat ugotovitev raziskave o predznanju študentov. Oblikovan je bil med cikličnim procesom akcijskega raziskovanja $\mathrm{z}$ udeležbo. Predstavljene so izkušnje na podlagi triletnega izvajanja modula in povratne informacije študentov, ki so bile pridobljene $\mathrm{s}$ pomočjo evalvacijskih vprašalnikov. Udeleženci so izkušnjo ocenili kot zelo pozitivno. Modul se jim je zdel zanimiv, pomemben in potreben za njihov poklic srednješolskega učitelja kemije. Poudarili so tudi, da se zdaj počutijo kompetentnejše na področju izobraževanja za trajnostni razvoj.

Ključne besede: izobraževanje za trajnostni razvoj, kemijsko izobraževanje, akcijsko raziskovanje $\mathrm{z}$ udeležbo, izobraževanje učiteljev 


\section{Introduction}

In a review of the role of Education for Sustainable Development (ESD) for and in secondary chemistry education, Burmeister, Rauch and Eilks (2012) previously discussed different justifications for covering ESD issues in the classroom, in teacher training, and in educational research. The special emphasis that chemistry education should have was demonstrated by showing the unique economic role of industrial chemistry in every developed society. The chemical industry provides most of the raw materials necessary for every other type of business and undertaking. It is the foundation of modern energy supply, agriculture, materials, communication, biotechnology, and medicine (Bradley, 2005). Burmeister et al. (2012) also referred to the impacts that chemistry-related technologies and industry have on the environment and on the social development of any society, both at local and regional levels.

Therefore, there is a justifiable need to implement learning about sustainability issues and ESD into chemistry teacher education. This paper reflects the development of such a course module in German pre-service chemistry teacher education. Developing the module was inspired by empirical investigations of the knowledge base of student teachers and practicing teachers in Germany (Burmeister \& Eilks, 2013; Burmeister, Schmidt-Jacob, \& Eilks, 2013). The development was done with the use of the model of Participatory Action Research (PAR) in science education (Eilks \& Ralle, 2002). The paper reflects experience gained during the three years of development, including feedback collected from student evaluation sheets.

\section{Education for Sustainable Development and chemistry education}

In several instances in the past, industrial chemistry practices did not reflect current ideas of sustainable development as defined by the Agenda 21 (UNCED, 1992). This led to industrial accidents, contributed to environmental pollution, and established production environments that did not always acknowledge sufficiently-modern social standards. However, a change in attitude has taken place in the chemistry field in recent decades, at least in Western societies. Today, industry is seeking cleaner chemical production pathways that decrease ecological pollution, lower raw material demands, and increase overall social harmony within societies (ECCC, 1993). Among the different available concepts, the central ideas of change are laid down in the basic philosophy of Green or Sustainable Chemistry (Anastas \& Warner, 1998; Centi \& Perathoner, 
2009). This goes hand-in-hand with a growing public awareness of both the finite nature of natural resources and the existence of limits regulating and determining feasible rates of growth (Meadows, Randers, \& Meadows, 1972; UNCED, 1992).

Ensuring sustainable development in an industrialised society means maintaining the overall supply levels of energy and goods, while simultaneously decreasing both the amounts of environmentally hazardous substances and overall raw material consumption (UNCED, 1992). Such development is impossible without advances in chemistry research and chemical technology (Bradley, 2005). However, sustainable chemistry has not yet been implemented throughout the world. Production methods in many countries do not even come close to being ecologically, economically, or societally sustainable. Even in societies with strong sustainability movements, the positive aspects and benefits of current chemical developments are often repressed in favour of quite often poorly-informed, biased mass media coverage. Balanced news coverage and evidence-based communication remain widely underdeveloped in many countries (Hartings \& Fahy, 2011). This means that chemistry education must help contribute to the development of a more balanced, better-reflected view among students, since they are future citizens, and are currently not receiving balanced media coverage of events. Chemistry education needs to promote both the knowledge and the skills necessary to allow students a place in society. This includes informed participation in societal debates as well as decisionmaking in cases in which society is making choices about science- and technology-related issues (Burmeister et al., 2012).

Such a balanced and critical view of chemistry requires a rethinking of chemistry education itself. Therefore, Burmeister et al. (2012) emphasised that reflections on the potential connections between chemistry and ESD should not only take subject content into account. They point out that rote memorisation of the subject matter underlying chemical and industrial applications will provide an insufficient basis for participating in real societal debates on modern chemistry and technology developments. One suggestion was to take modern educational concepts of school chemistry further into account when justifying ESD in chemistry education. Teaching objectives should reach far beyond any rote learning of chemical theories and facts in modern chemistry curricula, as discussed e.g. by Eilks, Rauch, Ralle and Hofstein (2013). Modern curricula and pedagogies of teaching should focus on the promotion of general educational skills. Learning how to participate in societal debates and to evaluate communication and available choices need to become overt topics in chemistry education (Eilks, Nielsen, \& Hofstein, accepted for publication). A 
more thorough focus on the societal-oriented, multi-dimensional character of chemistry education, as suggested by Hofstein, Eilks and Bybee (2011), offers a strong justification for combining chemistry education and ESD, including pedagogies that allow for learning how to participate in society (e.g. Eilks et al., 2013).

As a result, the central role of the chemical industry and technology in developing a society allots the central responsibility for contributing to ESD to the area of chemistry education. Furthermore, learning about how chemical developments themselves are interwoven with ecological, economic and societal impacts, including the decisions resulting from such issues, is of central importance. Recent societal developments can be linked directly to chemistry and technology, then be dealt with using a multidimensional, socio-scientific approach (Sadler, 2011). Using controversial socio-scientific issues, which are selected carefully with respect to chemical, industrial and technological questions, allows students the chance to experience first-hand exactly how societal questions related to science or technology are handled (Eilks et al., 2013). This approach has the potential to give the extra little impetus that is necessary to connect chemistry education and ESD. It can lead to the end goal of preparing the younger generation to contribute to the sustainable development of both the planet and the particular society in which they live (Ware, 2001).

It seems clear that chemistry education must contribute to ESD in a prominent manner. Unfortunately, this has not been the case in many science curricula in the past (Burmeister et al., 2012). Therefore, reform is desperately needed (Ware, 2001). If we take the most influential shareholders in effective innovations of teaching practice, i.e. the teachers (Anderson \& Helms, 2001) into account, reform might begin with innovations in teacher training. It is clear from educational research that taking teachers' beliefs, foreknowledge and attitudes into account in the reform process is a necessary and serious precondition for any effective reform (Haney, Czerniak, \& Lumpe, 1996). Reorienting teacher education to foster ESD is also a widely-acknowledged political goal (UNESCO, 2005b). This is why the current paper deals with developing a course module for pre-service chemistry teacher training on modern concepts of sustainability and ESD. The development is based on Participatory Action Research (Eilks \& Ralle, 2002) and is undergirded by empirical research about student teachers' and experienced teachers' viewpoints and prior knowledge (Burmeister \& Eilks, 2013; Burmeister et al., 2013). 


\section{Participatory Action Research for curriculum innova- tion in teacher education}

For almost a decade, the Participatory Action Research model (PAR) developed by Eilks and Ralle (2002) has been used in many projects for chemistry education curriculum development and classroom research (e.g. Eilks \& Markic, 2011; Eilks, Markic, \& Witteck, 2010). This model was originally inspired by a research approach borrowed from economics (Whyte, Greenwood, \& Lazes, 1989). It seeks to thoroughly connect domain-specific educational research, curriculum development and teaching practices. The basis for this model is the systematic use of empirical research evidence, which is connected to transformative actions in classroom teaching. The process of developing practices is performed in collaborative groups of in-service teachers and accompanying researchers. For innovations in school practice, teams of science educators from a university and teachers in schools are formed. They conduct the entire research and development process in a partnership setting (Eilks, accepted for publication).

The project described here represents one of the first approaches that transfers the PAR model outlined for school education reform to innovation for higher education. Not all assumptions of the model are valid regarding such a transfer, but the basic idea remains the same. Just as in school education, PAR for higher education seeks a cyclical optimisation of teaching practices, which are supported by research evidence. Equally valued information resources are combined at the beginning of the process. These include research evidence about teaching and learning processes in the specific domain, classroom curricula, reports of practitioners' personal experience, and the intuition and creativity of experienced people in the field (Figure 1; Eilks \& Ralle, 2002). This combination of resources takes into consideration both empirically validated research results and formally developed school curricula. It also adds the factor of experience-based teacher knowledge and student perspectives gained during learning. These two areas comprise both ends of the spectrum of teaching- and learning-based knowledge; each is valuable and has its own strengths (McIntyre, 2005). Because the same information resources are available, applying the PAR model to innovations for higher learning can be viewed as contributing to the same field of results. Therefore, the objectives targeted in the process encompass newly-developed curricula, teaching strategies and empirical evidence about teaching and learning in the field. They also include the reduction of any deficits reported in documented practice, which results in bettertrained professionals (Eilks \& Ralle, 2002). 
Action Research is generally described in the literature as being either the autonomous activity of the practitioner or, conversely, a cooperative process involving practitioners and external individuals (Mamlok-Naaman \& Eilks, 2012). The PAR model in science education as described by Eilks and Ralle (2002) is one of the later cases (Eilks, accepted for publication). This leads to one of the significant differences when transferring the PAR model to the field of higher education. In the case of school chemistry innovation, projects are driven by cooperation between in-service teachers and external science educators from the university. In this particular case, however, both groups - teaching practitioners and science educators - fall into the same category. However, we kept the team structure in all cases in which PAR was transferred to higher education innovations. Different practitioners are involved in the developmental research process, even though not all of them perform teaching functions in their respective classroom exercises. This approach maintains the opportunity to gather external viewpoints regarding practice, which is where innovation is actually thought to take place.

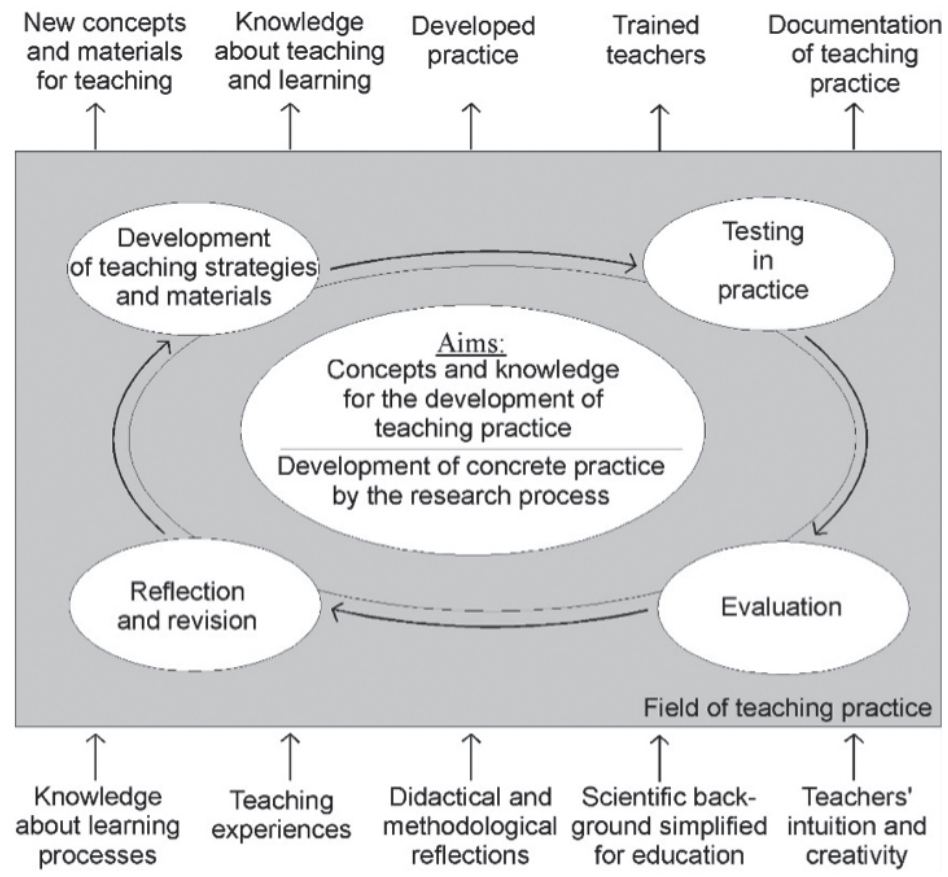

Figure 1: Participatory Action Research within domain-specific education (Eilks \& Ralle, 2002) 
The research process in the original PAR model is thought to be initiated when deficits in either teaching practices or empirical research are reported. PAR is then used to determine methods for eliminating or reducing any problems in teaching practice. This is also the case when transferring PAR to the realm of higher education. Research begins with a thorough analysis of the relevant literature. Group discussions within the research team are used to determine whether or not the problem is of general interest beyond the individual classroom. The discussions are also used to reflect upon whether or not evidence and ideas documented in the literature are feasible for offering help in the specific educational setting experienced by the practitioners.

All types of Action Research are cyclical in nature. This is one of the main differences between it and more conventional research designs (Eilks, accepted for publication). This is also the case in the approach chosen within this project. At the start, new teaching approaches are designed, then applied and tested. The objective is to cyclically improve teaching practices by applying newly-developed units in different testing groups. The prototype designs are used and tested as early as possible to see if they have the potential to solve specific problems in teaching practice. The process of planning in a group, or at least in a partnership of one practitioner and one accompanying researcher, is an crucial factor. This is not just because problems in evaluation/reflection can be avoided, but also because communication and reflection between the different practitioners/researchers ensure that each design is compatible with the needs of everyday teaching practices.

One central objective of any Action Research project is to improve practice step-by-step within each cycle of development. In order to do so, each of the cycles must be analysed and evaluated. However, the curricula are developed using close cycles of development and testing. It has been suggested, e.g. by Bodner, MacIsaac, and Whyte (1999), that classical strategies applying a quantitative understanding of evaluation are inappropriate for this kind of curriculum development. This is because there are far too many influencing factors, and the process includes the personal involvement of the researchers and practitioners. A qualitative and interpretative paradigm is more suitable in this situation. In this case, the validity of the interpretations can be tested communicatively during the discussions between accompanying persons and the teaching practitioners, and within the teaching practitioner group. The criteria as defined by Altheide and Johnson (1994) can be used as a guideline: plausibility, credibility, relevance and importance. If evaluation indicates that the curriculum changes are successful in reducing teaching and learning deficits, the development and research process can be continued in a new phase that will potentially lead to even more improvements. The newly-developed 
research phase must attempt to determine the reasons behind existing deficits, including the impact of any changes made during the previous round of research. The intention is to obtain general, yet relevant background information.

In the case study described here, the problem analysis yielded many official documents (as discussed in Burmeister et al., 2012) that called for a more thorough implementation of course content on ESD in German pre-service teacher training programs. The literature analysis supports claims that the implementation of subject matter addressing both sustainability theories and learning about ESD in chemistry teacher preparation is insufficiently developed in many countries (e.g. Summers \& Childs, 2007). This is why the cyclical PAR process was started in the present study and eventually led to three developmental cycles in three consecutive years of testing. Hard empirical evidence and precise information about student teachers' a priori knowledge, attitudes and beliefs in the case of German chemistry education were difficult to obtain at the beginning of the process. To overcome the lack in empirical support, several research initiatives were started in parallel to the curriculum development. They were meant to interact with and influence both curriculum development and the participants' understanding of its effects. One initiative included mapping out the knowledge base and attitudes of German student teachers and teacher trainees in the fields of sustainability and ESD, and where they are connected to chemistry education (Burmeister \& Eilks, 2013).

\section{German chemistry student teachers and trainee teachers' knowledge on sustainability and ESD}

Research on teachers' overall knowledge base, attitudes and beliefs concerning sustainability concepts and ESD is rare in the literature. Based on the few available studies from Germany and other countries (Seybold \& Rieß, 2006; Rieß \& Mischo, 2008; Summers \& Childs, 2007; Spiropoulou, Antonakaki, Kontaxaki, \& Bouras, 2007; Zachariou \& Kadij-Beltran, 2009) and in related fields, one can assume that German (student) teachers' knowledge of sustainability issues and the theories behind sustainable development might remain underdeveloped. This has already been shown by other studies on teachers' knowledge about the related field of climate change (Khalid, 2003; Papdimitriou, 2004) and their attitudes and pedagogical content knowledge (PCK) towards teaching respective issues (Feierabend, Jokmin, \& Eilks, 2011). The same might be true for the pedagogies developed for ESD-driven chemistry teaching. Nevertheless, for the case of chemistry education in the German context such documentation is quite difficult to find. 
The development of the course module was accompanied by various research studies in order to set the curriculum development process for innovating German teacher education on a broader pedestal. These studies were thought to describe pre-service teachers' knowledge base and attitudes towards sustainability, and the didactics and pedagogies of ESD in chemistry education. In one of the studies discussed in Burmeister and Eilks (2013), the level of understanding and knowledge student teachers $(\mathrm{N}=91)$ possessed at the beginning of their pre-service university training was mapped out based on questionnaires. The poll asked participants questions about contemporary and theory-based understandings of sustainable development and ESD. A second sample from Germany's compulsory, post-university teacher trainee program $(\mathrm{N}=97)$ was also acquired using the same tool. In both cases, the study researched candidates' knowledge, attitudes and ideas for potential action areas concerning sustainability issues and ESD in chemistry education.

Burmeister and Eilks (2013) described no major differences between both groups. They found positive attitudes among both student teachers and teacher trainees with regard to strengthening the link between sustainability issues and ESD in secondary school education. The participants acknowledged that all school subjects should contribute to ESD, but they also acknowledged a specific responsibility for chemistry education. Despite this positive attitude, their overall knowledge about potential topics and pedagogies in this area was limited and poorly thought out. There seems to be a lack of theoretically sound ideas about modern concepts of sustainability or a theory of ESD in the case of these trainees. However, the study also documented mostly positive attitudes among the candidates. Many student teachers and teacher trainees were headed in the right direction when asked for their knowledge about and association with sustainability and ESD. However, their ideas were raw, undeveloped and unsupported by substantial knowledge or theory. There were also many participants who were unable to mention any solid ideas or starting points for such a topic. Only an extremely small minority of the people questioned was able to outline a more-or-less complete description of what is meant by sustainable development. Almost no one had heard or could repeat what a theoretically-based description of ESD actually entails.

Overall, most future chemistry teachers in the two samples acknowledged that secondary school education should promote ESD, and that chemistry education should be a part of it. Some were able to associate topics from the chemistry curriculum with issues of sustainable development, e.g. with the question of the sustainable production of fuels. Yet ideas for using ESD in chemistry education, including how teaching might be structured by adequate 
pedagogies, remained extremely limited. Both samples explicitly mentioned that the participants had not yet been confronted with learning about sustainability or ESD pedagogies during their teacher training program. Both issues seem to play hardly any role in German teacher training programs. Neither chemistry courses, nor educational and domain-specific educational courses seem to address these issues explicitly so far. The participants mentioned that the major sources of their knowledge had been the informal media or from informational settings such as TV and the Internet. This strongly supports the premise of the current study that the development of explicit course content and modules to strengthen pre-service teachers' theoretical and practical knowledge for applying ESD are desperately needed in the field of chemistry education. Such statements offer starting points for connecting new knowledge to prior intuitive ideas. They also provide new topics and contexts, from which learning how to include ESD in chemistry education may begin, e.g. the questions of renewable energy sources or climate change. It also became clear that a theoretical foundation needs to start from the very bottom. It needs to include both learning about sustainability as such, the role of sustainable thinking in chemistry, and knowledge about practical pedagogies for effectively bringing ESD into the chemistry classroom.

\section{Structure of the course module}

The structure of the course developed in this project encompasses different topics. The course module has a duration of six weeks with one ninetyminute session per week. Table 1 gives an overview of the different sessions. The pedagogical ideas implemented in the learning process within the course module are presented in brief.

Table 1. Overview of the course module structure

\begin{tabular}{|l|l|}
\hline Session 1 & $\begin{array}{l}\text { - Assessing a priori knowledge and attitudes towards sustainability and ESD } \\
\text { using a research questionnaire } \\
\text { - Lecture on the historical genesis and modern concepts of sustainability } \\
\text { Overview on the course and introduction to a WebQuest for the issues of } \\
\text { sustainability and Green Chemistry }\end{array}$ \\
\hline Session 2 & $\begin{array}{l}\text { - WebQuest on issues of sustainability, the concept of Green Chemistry and } \\
\text { its perception in society } \\
\text { Role playing of different views towards Green Chemistry, inspired by the } \\
\text { WebQuest }\end{array}$ \\
\hline Session 3 & $\begin{array}{l}\text { - Jigsaw classroom on educational policy papers about ESD in German } \\
\text { school education }\end{array}$ \\
\hline
\end{tabular}




\begin{tabular}{|l|l|}
\hline Session 4 & $\begin{array}{l}\text { - Analysing a lesson plan on teaching about plastics with an ESD focus, } \\
\text { which mimics the product testing method in order to evaluate plastics in } \\
\text { the foreground of sustainability criteria }\end{array}$ \\
\hline Session 5 & $\begin{array}{l}\text { - Facultative: Further analysis and discussion of teaching materials } \\
\text { - Facultative: A board game on Green Chemistry in the chemical industry }\end{array}$ \\
\hline Session 6 & $\begin{array}{l}\text { - Lecture presentation summing up the course content } \\
\text { - Lecture presentation about basic models how to connect ESD and chemis- } \\
\text { try education } \\
\text { - Self-assessment of learning success with reference to the initial question- } \\
\text { naire and data about student teachers' knowledge on sustainability and } \\
\text { ESD from the accompanying research } \\
\text { - Reflection of the course content and structure }\end{array}$ \\
\hline
\end{tabular}

Inspired by the empirical study mentioned above (Burmeister \& Eilks, 2013), the coursework starts with a self-reflection activity (Table 1). This activity makes the participants explicitly aware of their a priori knowledge, their intuitive understanding of the topic, and their lack of theoretical foundation. This activity addresses findings from the research study, which show that many participants may have valuable ideas, but are perhaps unaware that such rough ideas do not form a sufficiently comprehensive basis for a theoretically embedded foundation. This activity is performed by asking the participants to fill out a questionnaire similar to the one used in the accompanying empirical study. This parallel approach allows researchers to reflect upon and compare participants' thoughts in a larger sample.

Beginning with the exposure of potential deficits in the participants' knowledge, the course then focuses on three key areas of learning (Table 1):

- The historical development and modern concepts of sustainability in general and their operationalisation in chemistry, especially through the concept of Green Chemistry;

- Learning about the basic theories and government legislation concerning ESD with particular focus on the practices of German chemistry education; and

- $\quad$ Learning about adequate pedagogies for acquainting school students with sustainability thinking in chemistry classes, promoting their understanding skills, and increasing their participation abilities in societal debates on questions of science and technology.

Contention with the basic theories behind sustainability is introduced through a short lecture, which presents the historical development of the term, the genesis of the Agenda 21, and an overview of competing concepts for modelling sustainability. The central focus in this phase is understanding 1) that in modern concepts of sustainability different dimension are interwoven and contain at least the ecological, economical, and social dimensions, and 2) that 
sustainability always is connected to balancing the interests and needs of today's society with the interests and chances of future generations. Learning about the importance of sustainability issues within chemistry and the chemical industry is structured using a WebQuest (a structured internet inquiry) designed for this course module (Burmeister, Jokmin, \& Eilks, 2011). The WebQuest introduces problems and issues arising from chemistry and the chemical industry connected to sustainable development. It explains chemical industries' efforts to contribute to sustainable development, but also presents critical voices. Learning via the WebQuest prepares the participants for a role-playing exercise, in which both the effort required and the chances represented are talked about by different role-players. This includes discussing critical roles that question whether the efforts undertaken are carried out in the correct fashion and are sufficiently intense in nature.

Contention with ESD theories takes place in a jigsaw classroom, based on different position papers taken from governmental bodies and educational societies. This cooperative learning scenario is used for analysing and comparing position papers from the Conference of the German State Ministries of Education (KMK), the German Society for Educational Sciences (DGfE), as well as the German hub of the UN world decade of Education for Sustainable Development (Transfer 21) (DGfE, 2004; KMK, 2007; Transfer 21, without year). This phase makes clear the importance that educational theory and educational policy give to ESD. It also shows that all school subjects, among them chemistry, are responsible for contributing to the knowledge of pupils about ESD.

The next learning phase for how to deal with ESD in school chemistry classrooms is based on a lesson plan developed by a group of teachers especially for this purpose (Burmeister \& Eilks, 2012). The development of this lesson plan also followed the PAR design but had innovations in the secondary chemistry classroom as its main goal. The lesson plan deals with the topic of plastics and handles the basic chemistry and properties of different polymer materials. The lesson plan focuses on ESD by combining the learning of essential chemistry content with information on how to evaluate chemistry products and technologies in the foreground of sustainability criteria. Within the lesson, the students learn essential chemistry theory, but they are also familiarised with the three dimensions of modern sustainability concepts. The pupils are asked to mimic consumer test agency workers in order to experience the interconnectedness of the three sustainability dimensions when evaluating chemistry products and technologies. Within the consumer test agency method, participants are asked to evaluate different sorts of plastics currently addressed by the sustainability debate, all of which have ecological, economic and societal implications. The 
pupils have to weigh the various dimensions against one another, evaluate the different plastics, and make a final evaluation. They learn about the different dimensions, including the fact that various aspects often negate one another when combined in a comprehensive evaluation. This activity is also mimicked by the student teachers during their coursework, then reflected upon with regard to its potential for influencing pupils' learning in a classroom setting. An optional board game dealing with Green Chemistry principles in industrial chemistry (Coffey, 2011) may be added if time allows.

The course closes with a session reflecting on the learned content and the present status of ESD implementation in German chemistry education. For this purpose, the four basic models for implementing ESD in chemistry education as described by Burmeister et al. (2012) are presented. This phase also refers back to the participant questionnaires, which were filled out at the beginning of the course. It also includes the research results described in Burmeister and Eilks (2013) and related findings from international studies on (student) teachers' understandings and views concerning sustainability issues and ESD in chemistry education.

\section{Feedback from the participants}

The course was applied in three cycles of development during three consecutive years of study. A total of 46 student teachers participated in the course. The different rounds of testing faced slight variations and improvements in the teaching materials. The first round was reflected on through group discussion occurring after the course $(\mathrm{N}=18)$. The second and third testing rounds were evaluated using a written questionnaire with open-ended questions and 32 Likert-items $(\mathrm{N}=28)$. The second and third rounds also conducted group discussions between the course teacher and the participants at the end of each of the testing rounds. All data from the evaluation were qualitatively analysed. The analysis was used for cyclical optimisation of the course, including insights into its feasibility and effects.

Overall, the participants responded very positively to the course. The student teachers stated that the course module was interesting, important and valuable for their later profession as chemistry teachers in a school. The student teachers also emphasised that they had learned a great deal and that they now felt more competent in the area of sustainability and ESD. A few example quotes from the open questionnaire can illustrate these claims:

"I consider it logical to offer such a seminar. Even if the term 'sustainable development' has been heard by the participants before, it was never rationally explained. Since this seminar, I now consider myself capable 
of explaining what 'sustainable development' is to another person." »The seminar was very productive, and for most of the participants it was a new topic. Presumably, some had heard about ESD, but not in sufficient detail."

»We now have a basic and solid insight into sustainable development, which can be acted upon by the students using the presented pedagogies."

»I personally consider the ESD lesson plan to be structured in a very interesting and diversified manner. I consider the lesson plan to be positive, as were the presented possibilities for implementing it in the coursework of chemistry teaching in school. Sensitisation for the topic was very successful. The diversity in methods resulted in variety and fun. I found it interesting to actively slip into the role of my pupils and to mimic the lesson plan."

»The seminar was planned in an interesting and diversified way - I liked this very much. Moreover, I have the feeling that I learned something that will be helpful to me in the future when I am a teacher."

The impressions from the open statements in the questionnaires and the group discussion were supported by the responses to the Likert items. Figure 2 gives an overview of selected items and the students' responses.

Criticism was rare and occurred only briefly in the questionnaires and the group discussions. In the first round of testing, individual students were concerned about non-optimal time management of the course and insufficiently recognisable learning objectives for each phase of learning. Some student teachers did not fully recognise the differences in some of the course materials, since some were structured as materials for teacher training while others were materials developed to be used in a secondary school classroom. The different kinds of materials, the roles they were expected to play, and the hoped-for learning outcomes were made more explicit in the second round of testing. Some criticism also arose initially, because certain phases dwelt overly long on political and societal aspects, rather than on chemistry and science factors. This was especially prevalent in the WebQuest and role-playing phases of the course. The emphasis was then changed by selecting different Web materials for the WebQuest according to the criticism mentioned by the participants. Due to improvements in the course structure and materials, criticism in both of these areas diminished in the third round of testing. 


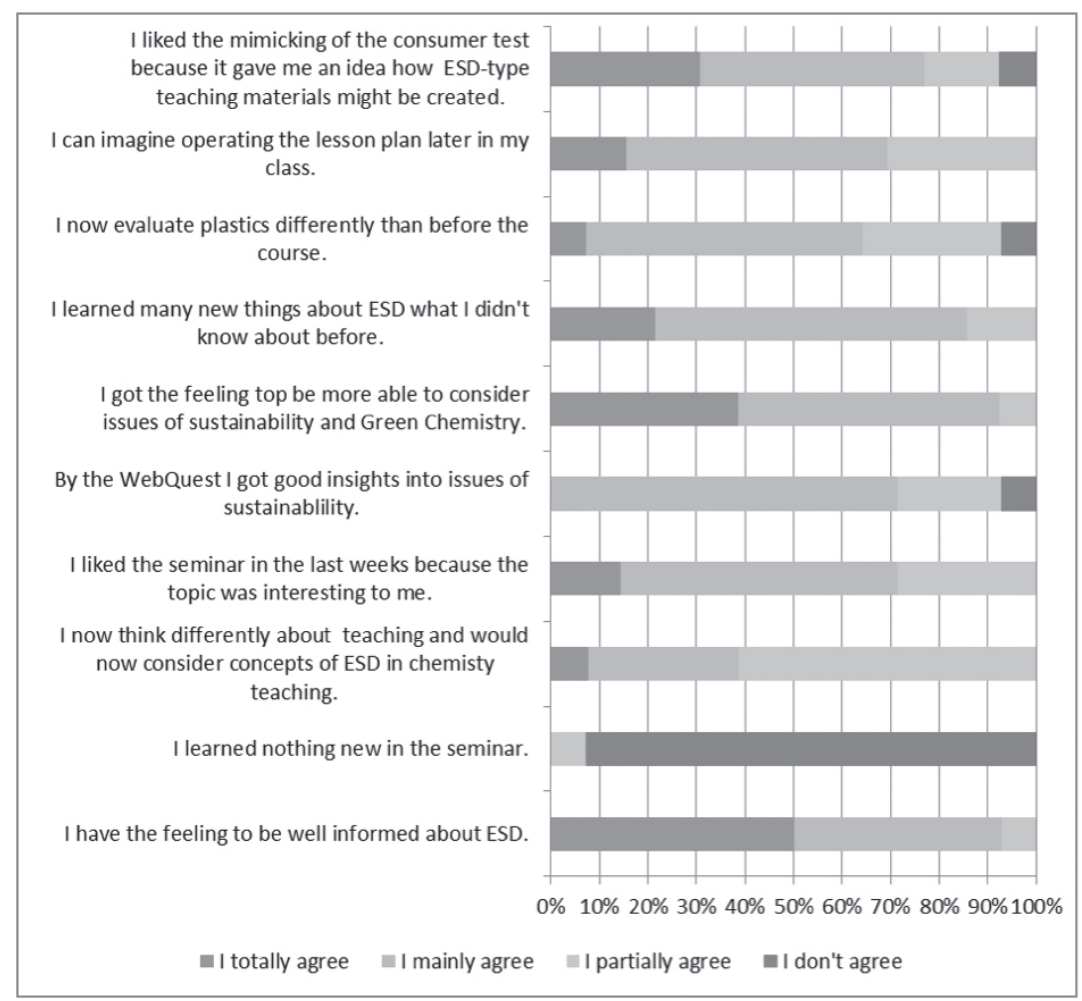

Figure 2. Selected Likert-items from the feedback questionnaire $(\mathrm{N}=\mathbf{2 8})$

\section{Conclusions and implications}

The end of the UN World Decade for Education for Sustainable Development, announced for 2005 to 2014 (UNESCO, 2005a), is drawing near. The focus of this decade was to thoroughly implement ESD in all fields of education, among them secondary school education in general and chemistry education in particular. The study discussed in Burmeister and Eilks (2013) documented that German student teachers and teacher trainees in chemistry have positive attitudes towards implementing ESD into their future teaching. However, the study also documented that their theoretically-based knowledge before teacher training and their acquired knowledge and skills during teacher training has thus far remained insufficient.

The case study described here offers an alternative to this. The current course module shows that it is possible to implement learning about sustainability issues and ESD into pre-service chemistry teacher training. The contents of the module proved valuable for offering future teachers ideas and pedagogies 
for familiarising themselves with sustainability issues. This included the connection of ESD with chemistry topics and modern pedagogies for implementing ESD in chemistry teaching. Student teacher feedback regarding this innovation was quite positive. The statements made by the participants seem to indicate that future teachers can and will be more sensitive and competent when dealing with sustainability issues and ESD in the chemistry classroom if they are allowed the opportunity to do so.

Reflection upon our experiences and findings tends to lead us assume that ESD practices will eventually be implemented in German chemistry teaching if the prospective teachers are allowed to learn about respective pedagogies. We can, however, assume that the current implementation rate is still low, because learning about ESD in connection to chemistry teaching is not yet a focus of chemistry teacher training in Germany. Unfortunately, hard evidence on the current state of concepts believed in and/or practiced by teachers in German chemistry classrooms is not yet available. Research in this field is still needed; one such study is under way. However, the fact that almost none of the student teachers brought any developed concept of sustainability in connection to chemistry topics from the school to the university is sobering. This would seem to indicate that such issues are not prominent topics in current chemistry classrooms in German secondary schools. This also means that pre-service chemistry teacher training programs must also be supported by training in the area of in-service chemistry teacher training with respect to sustainability and ESD. Single parts of the course module described above are currently being used for this purpose, e.g. in-service chemistry teacher training workshops about the WebQuest on Green Chemistry and the lesson plan on evaluating plastics. Perhaps these can contribute further to reducing deficits in in-service teachers' general knowledge about sustainability concepts and ESD in the same fashion as they did for pre-service teachers in this case study.

\section{References}

Altheide, D., \& Johnson, J. (1994). Criteria for assessing interpretative validity in qualitative research. In N. Denzin \& Y. Lincoln (Eds.), Handbook of Qualitative Research (pp. 485-499). Newsbury Park: Sage.

Anastas, P. T., \& Warner, J. C. (1998). Green Chemistry Theory and Practice. New York: Oxford University.

Anderson, R., \& Helms, J. V. (2001). The ideal of standards and the reality of schools: Needed Research. Journal of Research in Science Teaching, 38(1), 3-16.

Bodner, G., MacIsaac, D., \& White, S. (1999). Action Research: Overcoming the sports mentality 
approach to assessment/evaluation. University Chemistry Education, 3(1), 31-36.

Bradley, J. D. (2005). Chemistry education for development. Chemical Education International, 7.

Retrieved July o1 2011, from http://old.iupac.org/publications/cei/vol6/index.html

Burmeister, M., \& Eilks, I. (2012). An example of learning about plastics and their evaluation as a contribution to Education for Sustainable Development in secondary school chemistry teaching. Chemistry Education Research and Practice, 13(2), 93-102.

Burmeister, M., \& Eilks, I. (2013). Bildung für eine nachhaltige Entwicklung (BnE) in der Chemielehrerbildung - ein Projekt Partizipativer Aktionsforschung. Chemie konkret, 2o(2), advance article.

Burmeister, M., Jokmin, S., \& Eilks, I. (2011). Bildung für nachhaltige Entwicklung und Green Chemistry im Chemieunterricht. Chemie konkret, 18(2), 123-128.

Burmeister, M., Rauch, F., \& Eilks, I. (2012). Education for Sustainable Development (ESD) and secondary chemistry education. Chemistry Education Research and Practice, 13(2), 59-68.

Burmeister, M., Schmidt-Jacob, S., \& Eilks, I. (2013). German chemistry teachers' understanding of sustainability and Education for Sustainable Development - An interview case study. Chemistry Education Research and Practice, 14(2), advance article.

Centi, G., \& Perathoner, S. (2009). From green to sustainable chemistry. In F. Cavani, G. Centi, S. Perathoner, \& F. Trifiro (Eds.), Sustainable industrial processes (pp. 1-72). Weinheim: Wiley-VCH. Coffey, M. (2011). Green chemistry: Development of an educational board game. Paper presented at the Variety in Chemistry Education Conference, York, UK.

DGfE (2004). Memorandum zur Lehrerbildung für eine Nachhaltige Entwicklung (BfnE). Retrieved April 30, 2012, from www.umweltbildung.uni-osnabrueck.de/Dgfe-bne/Forschung ECCC (1993). Chemistry for a clean world. The Hague: European Communities Chemistry Council. Eilks, I. (accepted for publication). Action Research in science education - From a general justification to a specific model in practice. In F. Rauch, A. Schuster, A. Townsend, \& T. Stern (Eds.), Bringing a Different World into Existence: Action research as a trigger for innovations. London: Routledge.

Eilks, I., \& Markic, S. (2011). Effects of a long-term Participatory Action Research project on science teachers' professional development. Eurasia Journal of Mathematics, Science and Technology Education, 7(3), 149-160.

Eilks, I., \& Ralle, B. (2002). Participatory Action Research in chemical education. In B. Ralle \& I. Eilks, Research in Chemical Education - What does this mean? (pp. 87-98). Aachen: Shaker. Eilks, I., Markic, S., \& Witteck, T. (2010). Collaborative innovation of the science classroom by Participatory Action Research - Theory and practice in a project of implementing cooperative learning methods in chemistry education. In M. Valenčič Zuljan \& J. Vogrinc (Eds.), Facilitating Effective Student Learning through Teacher Research and Innovation (pp. 77-101). Ljubljana: University of Ljubljana.

Eilks, I., Nielsen, J. A., \& Hofstein, A. (accepted for publication). Learning about the role of science in public debate as an essential component of scientific literacy. In C. Bruguière, P. Clément, \& A. 
Tiberghien (Eds.), Book of selected presentations, ESERA Conference Lyon 2011. Dordrecht: Springer. Eilks, I., Rauch, F., Ralle, B., \& Hofstein, A. (2013). How to balance the chemistry curriculum between science and society. In I. Eilks \& A. Hofstein (Eds.), Teaching Chemistry - A studybook (pp. 1-36). Rotterdam: Sense.

Feierabend, T., Jokmin, S., \& Eilks, I. (2011). Chemistry teachers' views on teaching 'Climate Change' - An interview case study from research-oriented learning in teacher education. Chemistry Education Research and Practice, 11(1), 85-91.

Haney, J. J., Czerniak, C. M., \& Lumpe, A. T. (1996). Teacher beliefs and intentions regarding the implementation of science education reform strands. Journal of Research in Science Teaching, 33(9), 971-993.

Hartings, M. R., \& Fahy, D. (2011). Communicating chemistry for public engagement. Nature Chemistry, 3(9), 674-677.

Hofstein, A., Eilks, I., \& Bybee, R. (2011). Societal issues and their importance for contemporary science education: a pedagogical justification and the state of the art in Israel, Germany and the USA. International Journal of Science and Mathematics Education, 9(6), 1459-1483.

Khalid, T. (2003). Pre-service high school teachers' perceptions of three environmental phenomena. Environmental Education Research, 9(1), 35-50.

KMK (2007). Empfehlung der Ständigen Konferenz der Kultusminister der Länder in der Bundesrepublik Deutschland (KMK) und der Deutschen UNESCO-Kommission (DUK) vom 15.06.2007 zur „Bildung für nachhaltige Entwicklung in der Schule«. Retrieved April 30 2012, from www.kmk.org/fileadmin/pdf/PresseUndAktuelles/2007/KMK-DUK-Empfehlung.pdf Mamlok-Naaman, R., \& Eilks, I. (2012). Action research to promote chemistry teachers' professional development - Cases and experiences from Israel and Germany. International Journal of Mathematics and Science Education, 10(3), 581-610.

Meadows, D., Randers, J., \& Meadows, D. (1972). Limits to growth. New York: Universe. McIntyre, D. (2005). Bridging the gap between research and practice. Cambridge Journal of Education, 35(3), 357-382.

Papdimitriou, V. (2004). Prospective primary teachers' understanding of climate change, greenhouse effect, and ozone layer depletion. Journal of Science Education and Technology, 13, 299-307. Rieß, W. \& Mischo, C. (2008). Evaluationsbericht „Bildung für nachhaltige Entwicklung (BNE) an weiterführenden Schulen in Baden-Württemberg«. Stuttgart: Umweltministerium BadenWürttemberg.

Sadler, T. D. (2011). Socio-scientific Issues in the Classroom. Dordrecht: Springer.

Seybold, H.-J. \& Rieß, W. (2006). Research in environmental education and Education for Sustainable Development in Germany: the state of the art. Environmental Education Research, 12(1), $47-63$.

Spiropoulou, D., Antonakaki, T., Kontaxaki, S., \& Bouras, S. (2007). Primary teachers' literacy and attitudes on Education for Sustainable Development. Journal of Science Education and Technology, $16(4), 443-450$. 
Summers, M., \& Childs, A. (2007). Student science teachers' conceptions of sustainable development: an empirical study of three postgraduate training cohorts. Research in Science \& Technological Education, 25(3), 307-327.

Transfer 21 (without year). Orientierungshilfe Bildung für nachhaltige Entwicklung in der Sekundarstufe I Begründungen, Kompetenzen, Lernangebote.

UNCED (1992). Agenda 21. Retrieved July 10 2011, from www.un.org/esa/dsd/agenda21/ UNESCO (2005a). World decade of education for sustainable development. Retrieved July 10 2011, from http://www.unesco.org/new/en/education/themes/leading-the-international-agenda/educationfor-sustainable-development/

UNESCO (2005b). Guidelines and recommendations for reorienting teacher education to address sustainability. Retrieved July 10 2011, from unesdoc.unesco.org/images/o014/o01433/14337oe.pdf Ware, S. A. (2001). Teaching chemistry from a societal perspective. Pure and Applied Chemistry, 73(7), 1209-1214.

Whyte, W. F., Greenwood, D. J., \& Lazes, P. (1989). Participatory Action Research. The American Behavioral Scientist, 32(5), 513-551.

Zachariou, A., \& Kadji-Beltran, C. (2009). Cypriot primary school principals' understanding of education for sustainable development key terms and their opinions about factors affecting its implementation. Environmental Education Research, 15(3), 315-342.

\section{Biographical note}

MAreike Burmeister, Dr., studied Chemistry and Biology to become a secondary teacher at the University of Bremen. She finished her $\mathrm{PhD}$ in 2012 with a grant from the Deutsche Bundesstiftung Umwelt (DBU) at the Institute for Science Education at the University of Bremen, Germany.

INGo EILKS, Prof. Dr., FRSC, was a secondary school teacher in chemistry and mathematics. Since $\mathbf{2 0 0 4}$ he is a professor in chemistry education at the Institute for Science Education at the University of Bremen, Germany. 